\title{
Bio-based Natural Fibre Reinforced Green Composites
}

\author{
Aleksandra Voronova ${ }^{1}$, Ance Ziemele ${ }^{2}$, Anda Dzene ${ }^{3}$, Velta Tupureina ${ }^{4}$ \\ ${ }^{1-4}$ Riga Technical University
}

\begin{abstract}
The main goal of the presented study is the development of industrial hemp fibre reinforced biocomposites. Matrix materials used are as follows: thermoplastic starch based systems, blends of biodegradable polymers - poly(vinylalcohol) and microbially produced polyester polyhydroxybutyrate. The correlation among hemp fibre content, matrix composition and characteristics of biocomposites has been demonstrated. Hydrophobic finishing of reinforced biocomposites with Rucostar DDD diminishes moisture absorption. Biodegradation of biocomposites has been found to be composition dependent.
\end{abstract}

Keywords: biodegradable polymers, natural fibres, thermoplastic starch, mechanical properties

\section{INTRODUCTION}

In recent years much attention has been focused on the development and use of biodegradable composite materials based on the renewable resources as an eco-friendly alternative to traditional nondestructive synthetic plastic materials. The use of natural fibres as reinforcement in polymer composites has attracted special interest due to their availability, low cost, light weight, renewability, acceptable specific strength properties, ease of separation and biodegradability [1-4].

The present study is focused on the development of specific class of reinforced biocomposites denoted as "green composites", where bio-based polymers serve as a matrix for natural fibre reinforcement and both of them are derived from renewable resources and are fully biodegradable [1, 2-8].

The basic idea of our research is the selection, optimization and comparison of distinct matrix materials and the assessment of their suitability for designing of natural fibre reinforced "green composites".

Several potential biodegradable polymers have been selected to reach the above-mentioned aim: microbially produced polyester polyhydroxybutyrate (PHB), chemically synthesized polyvinyl alcohol (PVA), agropolymers (thermoplastic starch - TPS); moreover, various their blends have been developed as modified bio-based matrix material.

PHB as one of commercially available polyhydroxyalkanoates has attracted interest as a promising thermoplastic biopolymer due to its specific properties biodegradability, biocompatibility and hydrophobic nature [9, 10] and has been recognized as available raw material for a biodegradable polymer matrix. One of possibilities to improve inherent brittleness and thermal instability of hydrophobic PHB and to reduce high production costs can be assured through modification and blending with other types of biodegradable polymers [10-14]. The main goal of the present study is based on such an approach - the elaboration of novel waterborne polymer matrix systems - blends of hydrophobic PHB (in the powder or latex form) with hydrophilic partner components - TPS or/and PVA - for the development of hemp fibre reinforced biocomposites and the analysis of mechanical, hygroscopic properties and biodegradability of the obtained biocomposites.

\section{MATERIALS AND METHODS}

$\underline{\text { Materials }}$

Matrix materials used were as follows:

PHB powder from "Biomer ${ }^{\circledR}$ " (Germany) - M.w. 540 kDa, $\mathrm{T}_{\mathrm{m}}=176{ }^{\circ} \mathrm{C}, \mathrm{T}_{\mathrm{dec}}=200 \ldots 22{ }^{\circ} \mathrm{C}$, degree of crystallinity of $61 \%$, density of $1.25 \mathrm{~g} / \mathrm{cm}^{3}, \sigma_{\mathrm{T}}=31 \ldots 40 \mathrm{MPa}, \varepsilon_{\mathrm{br}}=3 \%$.

PHB latex - the aqueous suspension of colloidal PHB native granules, prepared at the University of Latvia (LU MBI) from microbially synthesized PHB (Azotobacter croocoсиит 23) biomass (optimal concentration in the range of $170-200 \mathrm{~g} / \mathrm{l}, \mathrm{T}_{\mathrm{m}}=177^{\circ} \mathrm{C}$ ).

PVA - partially crystalline, water soluble, 98.0...99.2\% hydrolyzed, M.w. $131 \mathrm{kDa}, \mathrm{T}_{\mathrm{m}}=228^{\circ} \mathrm{C}, \mathrm{T}_{\mathrm{dec}}=230^{\circ} \mathrm{C}$, density in the range of $1.2 \ldots 1.3 \mathrm{~g} / \mathrm{cm}^{3}$.

Glycerin - used as PVA plasticizer; density of $1.26 \mathrm{~g} / \mathrm{cm}^{3}$, $\mathrm{T}_{\text {boil }}=290{ }^{\circ} \mathrm{C}$.

Thermoplastic starch (TPS) - a commercial product from "Biotec TPS" - water soluble, density in the range of $1.3 \ldots 1.5 \mathrm{~g} / \mathrm{cm}^{3}$, moisture content in the range of $2.5 \ldots 4.5 \%$.

Native potato starch supplied by Aloja Starkelsen Ltd. (Latvia); moisture content of $20 \%, \mathrm{pH}=7$.

Reinforcement - industrial hemp fibre Bialobrezskie (Poland brand, cultivated in Latvia); composition (\%): cellulose -66.4 ; hemicellulose -18.8 ; lignin -5.7 ; pectin 1.5; wax and grease -0.5 . Fibre was chopped by Retsch Ultra Centrifugal Mill into lengths of $3 \mathrm{~mm}$.

Rucostar DDD - fluor containing, cation active nanopolymer for fibre finishing with a triple effect: hydrophobic and oleophobic finish and lubrication. For use in the present study, Rucostar DDD was diluted 1:1 with water.

The formation process of hemp fibre reinforced biocomposites was performed by a solution casting technique based on the so-called "wet process", i.e., preparing water solutions or dispersions of the selected biopolymers (PVA, PHB, TPS) as a continuous matrix and incorporating hemp fibre by blending in high-intensity mixer VITEK-VT1408 $250 \mathrm{~W}(15 \ldots 20 \mathrm{~min})$ in order to obtain homogenous material (Fig. 1). 
Mixing of PHB powder in the matrix was assured by grinding in a special glass pearl mill. After drying biocomposites were compression moulded at $180 \ldots 200{ }^{\circ} \mathrm{C}$ into $0.2 \ldots 0.5 \mathrm{~mm}$ plates.

Testing Methods

Mechanical characteristics were determined by Zwick Roell Testing machine in accordance with LVS EN ISO 527-3 (v = $10 \mathrm{~mm} / \mathrm{min}$ ). Moisture absorption was measured according to ASTM D585 (RH $=98 \%)$. Laboratory accelerated soil degradation tests were carried out gravimetrically at $25{ }^{\circ} \mathrm{C}$ in the microbially active garden soil $(\mathrm{pH}=6.5$; water content in the range of $22 \ldots 24 \%$ ).



Fig. 1. The formation process of hemp fibre reinforced biocomposites

\section{RESULTS AND DISCUSSION}

The present study concerns the development of hemp fibre reinforced "green composites" based on a biodegradable matrix from renewable resources - mainly agro-polymers and modified systems of their representative - TPS as low-cost, annually renewable and biodegradable material. The chosen strategy focuses specifically on the designing of several series of modified TPS blends in order to obtain biodegradable multiphase matrix materials with natural fibre (hemp) and to analyse the effect of such systems on the mechanical properties and biodegradability of biocomposites.

Preparation method of different matrix systems containing mixtures of TPS with PVA, PHB powder or latex was elaborated and the use of these matrix systems for the development of reinforced biocomposites tested and compared with a previously employed matrix - blends of biopolymers PVA/PHB [15].

The formation process of PHB latex films from colloidal native granule suspension was developed earlier [16] and main preconditions for ensuring film forming properties were ascertained. Characterization of the used matrix systems and biocomposites is explained below (Table I).

The effect of matrix compositions on the mechanical characteristics of the obtained hemp reinforced biocomposites was ascertained. Fig. 2 shows the mechanical characteristics of the obtained hemp fibre reinforced biocomposites based on the modified TPS matrix systems obtained by the abovementioned solvent casting technique with a subsequent compression moulding process.
As seen in Fig. 2, tensile strength $\left(\sigma_{t}\right)$ of TPS based biocomposites with 30 wt.\% fibre reinforcement shows $\sim 2-$ fold increase in the $\sigma_{t}$ of pure TPS.

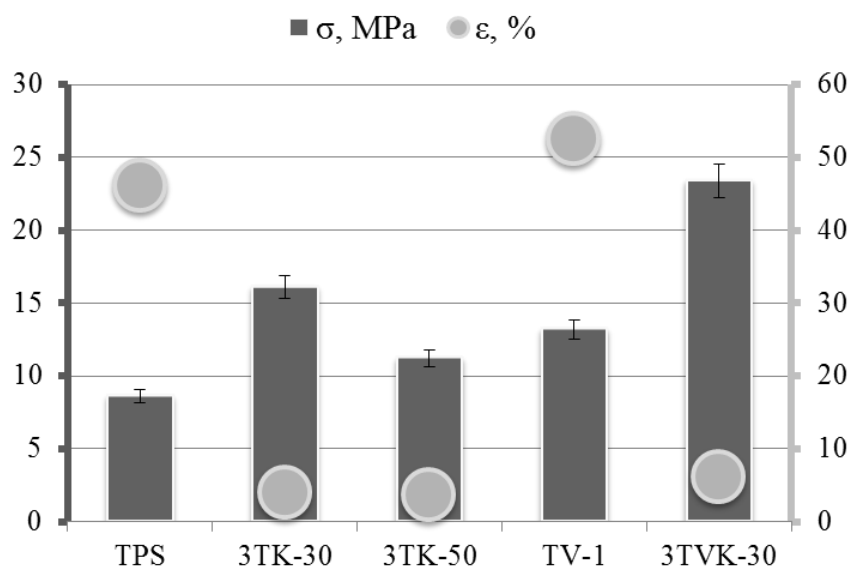

Fig. 2. Tensile strength $\left(\sigma_{\mathrm{T}}\right)$ and elongation at break $(\varepsilon)$ of TPS based matrix

An increase in the fibre content up to $50 \mathrm{wt} \%$ did not improve $\sigma_{\mathrm{t}}$ and as it was clarified earlier [15] the optimal fibre content by the applied mixing technology was found to be at the level of $30 \mathrm{wt} \%$ using $3 \mathrm{~mm}$ long fibre. Such fibre characteristics were employed for all further biocomposites. Fig. 2 shows the mechanical response from different types of TPS based matrix compositions. It was revealed that the best results in terms of mechanical strength were ensured for the TPS/PVA matrix $\left(\sim 3\right.$-fold increase of $\left.\sigma_{\mathrm{T}}\right)$, which could be explained by the compatibility of PVA and starch [14] and the interaction possibility of similar functional groups in the structure of hemp and starch.

Incorporation of $\mathrm{PHB}$ in the TPS matrix resulted in somewhat lower $\sigma_{\mathrm{T}}$ values likely due to insufficient homogeneity of material and imperfect bonding between fibre and matrix, which needs to be studied in further research. Mechanical characteristics of different elaborated matrix systems and such matrix based hemp fibre reinforced biocomposites are summarized in Table I.

The obtained results testify that the best results in terms of mechanical strength were ensured by the use of PVA containing matrix for both types of matrix systems: $\sigma_{\mathrm{T}} \sim 23$ $\mathrm{MPa}, \mathrm{E}_{\mathrm{T}}>500 \mathrm{MPa}-\mathrm{TPS}$ based matrix, $\sigma_{\mathrm{T}} \sim 34 \mathrm{MPa}, \mathrm{E} \varepsilon>$ $600 \mathrm{MPa}$ - starch containing PVA/PHB matrix.

As all biocomposites are heat treated, mechanical strength improvement of biocomposites containing PVA could be explained by the presence of double bonds in the main chain of PVA resulting in higher heat stability and promoting a more ordered structure and increased crystallinity of PVA [17]; such probability needs to be studied in detail.

Differential scanning calorimetry (DSC) measurements of individual PVA and PHB powders (heating/ cooling rate $10^{\circ} \mathrm{C} / \mathrm{min}$.) show that these biopolymers are thermodynamically incompatible (Fig. 3). However, combined in a film, they show a more complex behaviour, and the PHB and PVA matrix interaction can be achieved. 
TABLE 1

COMPOSITION AND MECHANICAL CHARACTERISTICS OF BIO-BASED MATRIX AND HEMP REINFORCED BIOCOMPOSITES

\begin{tabular}{|l|c|c|c|l|}
\hline \multicolumn{1}{|c|}{ System } & $\sigma_{\mathrm{T}}, \mathrm{MPa}$ & $\varepsilon_{\mathrm{b}}, \%$ & $\mathrm{E}_{\mathrm{T}}, \mathrm{MPa}$ & \multicolumn{1}{c|}{ Composition, ratio } \\
\hline TPS matrix & 8.6 & 46.2 & 92 & $15 \%$ of water solution \\
\hline 3TK-30 & 16.1 & 4.0 & 520 & $0.7 \mathrm{~T}: 0.3 \mathrm{~K}$ \\
\hline TV-1 matrix & 13.2 & 52.6 & 125 & $1.0 \mathrm{~T}: 0.5 \mathrm{~V}$ \\
\hline 3TVK-30 & 23.4 & 6.1 & 595 & $0.7(1.0 \mathrm{~T}: 0.5 \mathrm{~V}): 0.3 \mathrm{~K}$ \\
\hline TVH-1 matrix & 9.2 & 4.9 & 242 & $1.0 \mathrm{~T}: 0.5 \mathrm{~V}: 0.5 \mathrm{H}$ \\
\hline 3TVHK-30 & 21.1 & 5.2 & 675 & $0.7(1.0 \mathrm{~T}: 0.5 \mathrm{~V}: 0.5 \mathrm{H}): 0.3 \mathrm{~K}$ \\
\hline TVHal-1 matrix & 7.9 & 26.2 & 88 & $1.0 \mathrm{~T}: 0.5 \mathrm{~V}: 0.5 \mathrm{Hal}$ \\
\hline 3TVHalK-30 & 16.9 & 3.7 & 695 & $0.7(1.0 \mathrm{~T}: 0.5 \mathrm{~V}: 0.5 \mathrm{Hal}): 0.3 \mathrm{~K}$ \\
\hline TVGH-1 matrix & 5.3 & 4.9 & 123 & $1.0 \mathrm{~T}: 0.5(1.0 \mathrm{~V}: 0.3 \mathrm{G}): 0.5 \mathrm{H}$ \\
\hline 3TVGH-30 & 16.9 & 6.8 & 466 & $0.7 \mathrm{TVGH}: 0.3 \mathrm{~K}$ \\
\hline PVPH-50 matrix & 15.0 & 25.2 & - & $1.0 \mathrm{~V}: 0.3 \mathrm{G}: 0.5 \mathrm{H}$ \\
\hline 3PVHK-30 & 30.2 & 7.5 & - & $0.7 \mathrm{PVPH}-50: 0.3 \mathrm{~K}$ \\
\hline PVPHal-50 matrix & 19.9 & 268 & - & $1.0 \mathrm{~V}: 0.3 \mathrm{G}: 0.5 \mathrm{Hal}$ \\
\hline 3PVHalK-30 & 34.2 & 7.8 & 688 & $0.7 \mathrm{PVPHal}-50: 0.3 \mathrm{~K}$ \\
\hline PVC-50 matrix & 18.7 & 7.4 & - & $1.0 \mathrm{~V}: 0.3 \mathrm{G}: 0.5 \mathrm{C}$ \\
\hline 3PVCK-30 & 36.8 & 7.2 & - & $0.7 \mathrm{PVC}-50: 0.3 \mathrm{~K}$ \\
\hline PVHC-50 matrix & 10.3 & 13.1 & 253 & $1.0 \mathrm{~V}: 0.3 \mathrm{G}: 0.5 \mathrm{C}: 0.5 \mathrm{H}$ \\
\hline 3PVHC-30 & 38.9 & 7.9 & - & $0.7 \mathrm{PVHC}-50: 0.3 \mathrm{~K}$ \\
\hline 3PVHCK-40 & 33.1 & 6.0 & 1048 & $0.6 \mathrm{PVHC}-50: 0.4 \mathrm{~K}$ \\
\hline
\end{tabular}

Note: T - TPS; V - PVS; H - PHB; (Hal - PHB latex); C - potato starch;

Biocomposites: 3 - fibre length, mm; 20, 30, 40, 50 - fibre content, wt.\%.



Fig. 3. DSC measurements of PVA and PHB powders

As natural fibres and TPS are hydrophilic materials, the evaluation of moisture absorption of TPS based hemp reinforced biocomposites is of special importance. The effect of matrix composition on the moisture absorption of obtained hemp fibre reinforced biocomposites has been verified (Fig. 4 and Fig. 5).

It has been ascertained that hemp reinforcement and incorporation of hydrophobic PHB in the TPS based matrix promotes diminishing of moisture absorption of biocomposites (Fig. 4).

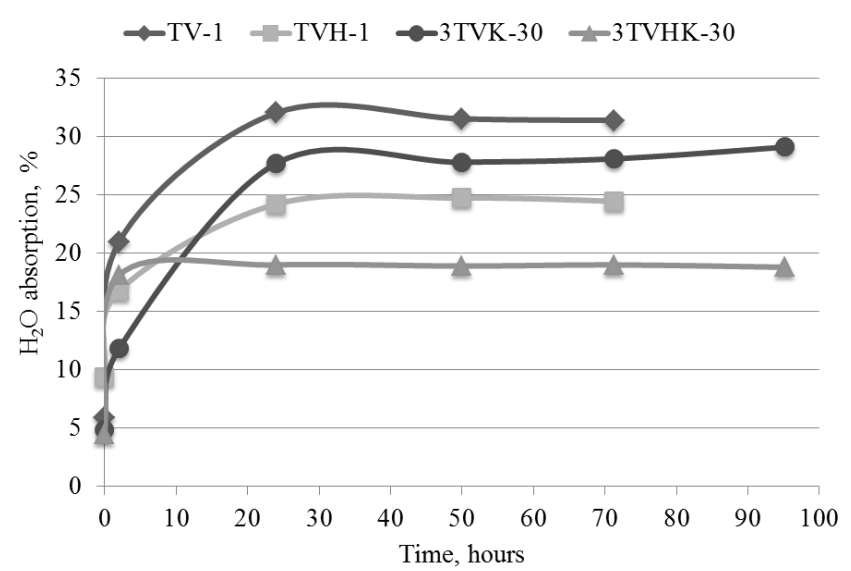

Fig. 4. Moisture absorption of TPS based matrix

To further improve the moisture resistance of hemp reinforced biocomposites, some attempts of hydrophobic finishing with Rucostar DDD (with subsequent heat treatment at $160{ }^{\circ} \mathrm{C}$ ) were performed (Fig. 5). The first results have testified the affirmative influence of the used finishing method and, therefore, it is intended to continue research in such a direction. 




Fig. 5. The influence of hydrophobic finishing on the moisture absorption of hemp fibre reinforced biocomposites

Susceptibility to biodegradation in soil of the prepared hemp fibre reinforced biocomposites was tested gravimetrically, by monitoring the time-dependent weight loss in garden soil. The biodegradation rate dependent on the matrix composition was found. The use of TPS based matrix and the addition of starch to the PHB/PVA matrix significantly facilitated the biodegradation process - their mass loss during 2...3 months reached $60 \ldots 80$ wt. $\%$ of the initial weight (Fig. 6).

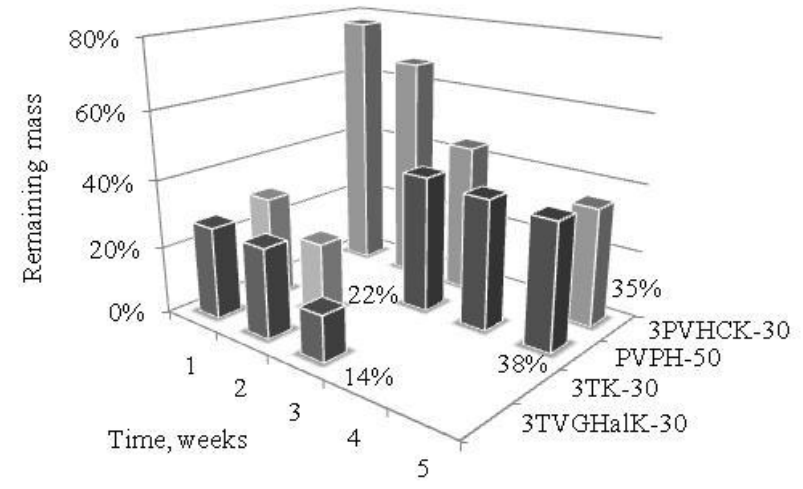

Fig. 6. Biodegradation rate of hemp fibre reinforced biocomposites in soil

\section{CONCLUSIONS}

The formation process of several novel biodegradable polymer (TPS, PVA, PHB) based waterborne systems has been elaborated and the use of these systems as a continuous matrix for the development of hemp fibre reinforced biocomposites by a suspension casting technique has been assured.

The relation between polymer matrix compositions and mechanical characteristics and biodegradability of biocomposites has been established. The best results in terms of mechanical strength for TPS based hemp fibre reinforced (30 wt.\%) biocomposites have been achieved by the addition of PVA $\left(\sigma_{\mathrm{T}} \sim 23 \mathrm{MPa}, \mathrm{E}_{\mathrm{T}}>500 \mathrm{MPa}\right)$; for PVA/PHB blends containing matrix - by the incorporation of native starch $\left(\sigma_{\mathrm{T}} \sim\right.$ $39 \mathrm{MPa}, \mathrm{E}_{\mathrm{T}}>900 \mathrm{MPa}$ ). Such phenomena could be explained by structure similarity of hemp and starch, and interaction of functional groups.

DSC measurements of PVA/PHB blends express a complex thermal behaviour as the evidence of variable interaction of these polymers.

It has been found that the use of PHB containing matrix and hydrophobic finishing with Rucostar DDD promotes diminishing of moisture absorption.

The biodegradation rate in soil of hemp fibre reinforced biocomposites has been found to be matrix composition dependent. The use of TPS based and starch containing matrix facilitates the biodegradation process.

Summary of the obtained results testifies that a number of designed waterborne matrix systems offer the scope for the development of natural fibre reinforced "green" biocomposites with controllable mechanical characteristics and biodegradability.

\section{REFERENCES}

1. Mohanty A.K., Misra M., Drzal L.T. Sustainable Bio-Composites from Renewable Resources: Opportunities and Challenges in the Green Materials World. Journal of Polymers and the Environment, 2002, vol. 10, N 1/2, April, p. 19-26. http://dx.doi.org/10.1023/A:1021013921916

2. Mohanty A.K., Tummala P., Liu W., Misra M., Mulukutla P.V., Drzal L.T. Molded Biocomposites from Soy Protein Based Bioplastic and Short Industrial Hemp Fiber. Journal of Polymers and the Environment, 2005, vol. 13, N 3, July, p. 279-285. http://dx.doi.org/10.1007/s10924-005-4762-6

3. Mehta G., Mohanty A.K., Thayer K., Misra M., Drzal L.T. Novel Biocomposites Sheet Molding Compaunds for Low Cost Housing Panel Applications. Journal of Polymers and the Environment, 2005, vol. 13, N 2, April, p. 169-175. http://dx.doi.org/10.1007/s10924-005-3211-x

4. Satyanarayana K.G., Wypych F. Characterization of Natural Fibers. In: Fakirov S. Handbook of Engineering Biopolymers, Carl Hansen Verlag, Munich, 2007, p. 3-47.

5. Zini E., Scandola M. Green Composites: An Overview. Polymer Composites, 2011, vol. 32, N 12, p. 1905-1915 http://dx.doi.org/10.1002/pc.21224.

6. Green Chemistry and bioplastics. Fact Sheet. European Bioplastics, September 2011, 4 pp.

7. Maya J.J., Sabu T. Biofibres and Biocomposites: Review. Carbohydrate $\begin{array}{lllll}\text { Polymers, } & 2008, & \text { vol. } & 71, & \text { p. }\end{array}$ http://dx.doi.org/10.1016/j.carbpol.2007.05.040.

8. Satyanarayana K.G., Arizaga G., Wypych F. Biodegradable Composites Based on Lignocellulosic Fibers: An overview. Progress in Polymer Science, 2009, vol. 34, p. 982-1021 http://dx.doi.org/10.1016/j.progpolymsci.2008.12.002.

9. Corre Y.-M., Bruzand S., Audic J.-L., Grohens Y. Morphology and Functional Properties of Commercial Polyhydroxyalkanoates: A Comprehensive and Comparative Study. Polymer Testing, 2012, vol. 31, p. 226-235 http://dx.doi.org/10.1016/j.polymertesting.2011.11.002.

10. Sreekumar P.A., Thomas S. Matrices for Natural-Fiber Reinforced Composites. In: Properties and Performance of Natural-Fiber Composites. Ed. by Kim L. Pickering, Woodhead Publishing Limited, 2008, p. 67-126. $\quad$ http://dx.doi.org/10.1201/9781439832141.ch2 http://dx.doi.org/10.1533/9781845694593.1.67

11. I.Smeltere, A.Dzene, V.Tupureina. Modification of Thermoplastic Starch. Scientific Proceedings of Riga Technical University. Series: Material Science and Applied Chemistry, 2006, vol.12, p. 69-75.

12. Yu L., Dean K., Li L. Polymer Blends and Composites from Renewable Resources. Prog. Polym. Sci., 2006, vol. 31, p. 576-602. http://dx.doi.org/10.1016/j.progpolymsci.2006.03.002

13. Data C. Starch as a Biopolymer in Construction and Civil Engineering. In: Handbook of Bioplastics and Biocomposites. Engineering Application. 2011, Willey, p. 317-343. 
14. Ke T., Sun X.S. Poly (lactic acid), and Poly (vinyl alcohol) Blends. Journal of Polymers and the Environment, 2003, vol. 11, N 1, January, p. 7-14. http://dx.doi.org/10.1023/A:1023875227450

15. L.Laiveniece, V.Tupureina, A.Dzene Hemp Fiber Reinforced Biocomposites. In: $3^{\text {rd }}$ International Conference on Innovative Natural Fiber Composites for Industrial Applications, Rome, Italy, October 1214, 2011. Abstract. CD.

16. Paṇēmiens agroḳimikāliju un/vai dabas antimikrobiālu piedevu saturošu biodegradējamu biokompozītu izgatavošanai. A.Dzene, S.Gonta, M.Kalniņš, L.Savenkova, V.Tupureina. LV Patents 13906B, 20 jūnijs, 2009 (in Latvian).

17. Gohil J.M., Bhattacharyana A., J., Ray P. Studies on the Cross-linking of Poly (vinyl alcohol). J. Polym. Res. 2006, vol. 13, p. 161-169. http://dx.doi.org/10.1007/s10965-005-9023-9

Aleksandra Voronova, Doctoral student at the study programme "Materials Science". She received her M.sc.ing. (2012) and B.sc.ing. (2010) from Riga Technical University, the Faculty of Materials Science and Applied Chemistry. Research interests: biodegradable polymer films and coatings and various polymer characterization methods. The results of research have been presented in both local and international conferences.

Address: Azenes Str. 14/24, LV-1048, Riga, Latvia

Phone: + 37128738378

E-mail: aleksandra.voronova@rtu.lv

Ance Ziemele, M.sc.ing., student at Riga Technical University. She received her B.sc.ing. in Materials Science from Riga Technical University, the Faculty of Materials Science and Applied Chemistry in 2012. Research interests: natural fibre reinforced biocomposites. The results of research have been presented in 2 international scientific conferences. Address: Azenes Str. 14/24, LV-1048, Riga, Latvia E-mail: senbiju@inbox.lv

Anda Dzene, Dipl.-Ing., Researcher at Riga Technical University. A.Dzene graduated from Riga Polytechnical Institute in 1961 and received her Dipl.Ing. degree in Chemical Technology. Since 1965 A.Dzene has been working at Riga Technical University. Since 2007 she is a Researcher at the Institute of Polymer Materials (Faculty of Materials Science and Applied Chemistry). Research interests: biopolymers, technology of modified biodegradable biocomposites. The results of the research have been approbated in more than 30 scientific publications, 3 Latvian patents and reports in $\sim 15$ international scientific conferences.

Address: Azenes Str. 14/24, LV-1048, Riga, Latvia

E-mail: anda.jugla@inbox.lv

Velta Tupureina, M.sc.ing., Researcher at Riga Technical University, the Faculty of Material Science and Applied Chemistry, Institute of Polymer Materials. V.Tupureina is the author of more than 200 scientific publications in the field of polymer chemistry and technology. Main scientific interests are related to biodegradable polymers and their modified and reinforced systems. Main elaborated biodegradable polymer systems are protected by 3 patents of Latvia.

Address: Azenes Str. 14/24, LV-1048, Riga, Latvia

Phone: + 37167089219 , Fax: + 37167615765

E-mail: velta.tupureina@ rtu.lv

\section{Aleksandra Voronova, Ance Ziemele, Anda Dzene, Velta Tupureina. Ar dabas šksiedrām stiegroti dabai draudzīgi biokompozīti}

Biokompozītu veidošana ar dabas šķiedru stiegrojumu, kā viens no šķiedru daudzpusīgas izmantošanas veidiem, piesaista arvien lielāku interesi, pateicoties plašai škiedru izplatībai, labvēlīgiem augšanas apstākḷiem, atjaunošanās un biosadalīšanās spējai, kā arī nelielām izmaksām un atbilstošam īpašību klāstam konkrētam pielietojumam. Pētījuma mērķis ir izveidot ar dabas šķiedru - industriāliem kaņepājiem stiegrotus specifiskus daudzkomponentu biokompozītus, kuri klasificējami kā „,zaļie ekokompozīti”, jo gan polimērmatrica, gan kaņepāju stiegrojums iegūti no atjaunojamām izejvielām un ir biologíski noārdāmi noteiktos apstākḷos un vidēs pēc izstrādājumu ekspluatācijas laika beigām. Izvēlēti divu veidu matricu materiāli un novērtēta to piemērotība ar kaņepājiem stiegrotu biokompozîtu veidošanai: termoplastiskās cietes (TC) sistēmas un biosadalošos polimēru - polivinilspirta (PVS) un mikrobiologiski sintezēta poliestera (PHB) maisījumi. Aprobēta stiegroto biokompozītu iegūšanas tehnolog̣ija, dispergéjot kaņepājus izvēlētā sastāva polimērmatricu ūdens sistēmās ar sekojošu žāvēšanu un termoapstrādi. Noskaidrota polimērmatricu sastāva un kaņepāju satura ietekme uz biokompozītu deformatīvajiem raksturojumiem, mitruma absorbciju un biosadalīšanās kinētiku. Optimālu mehānisko stiprību nodrošina 30 mas.\% šķiedras saturs. Konstatēts, ka PHB klātbūtne polimērmatricas sastāvā un polimērmatricu pēcapstrāde ar hidrofobizatoru Rucostar DDD samazina mitruma absorbciju. Biokompozītu sastāvs būtiski ietekmē to biosadalīšanās spēju augsnē. Eksperimentu rezultāti liecina par iespēju izmantot atšķirīga sastāva polimērmatricas stiegrotu biokompozītu veidošanai ar samērā plašu īpašību klāstu un regulējamu biosadalīšanās spēju.

\section{Александра Воронова, Анце Зиемеле, Анда Дзене, Велта Тупурейна. Биокомпозиты армированные натуральным волокном} Среди традиционных областей применения натуральных волокон особое место занимает их использование для армирования биокомпозитов, благодаря широкому распространению и возможностям натуральных волокон, их биоразлагаемости и комплексу соответствующих характеристик для разработки конкретных материалов и изделий. Целью исследования является разработка специфических многокомпонентных биокомпозитов, армированных натуральным волокном - индустриальной коноплей, которые классифицируются как экокомпозиты. Это связано с тем, что основные компоненты композиционного материала - полимерная матрица и армирование (конопля) - являются биоразлагающимися материалами, получаемыми из возобновляемого сырья и биологически разлагающимися при определенных условиях окружающей среды в конце эксплуатационного цикла изделий. Опробована пригодность использования двух видов полимерных матриц для изготовления биокомпозитов - систем термопластичного крахмала (ТК) и модифицированных смесей биоразлагаемых полимеров - поливинилового спирта (ПВС) и микробиально синтезированного термопласта полигидроксибутирата (ПГБ). Апробирована технология изготовления биокомпозитов методом отлива из водных систем разработанных полимерных матриц, армированных волокном, с последующей сушкой и термообработкой. Выяснено влияние состава полимерных матриц и содержания волокна на изменения механических характеристик, абсорбцию влаги и кинетику биоразложения полученных биокомпозитов. Установлено, что оптимальную прочность биокомпозитов обеспечивает содержание 30 вес.\% конопли. Присутствие ПГБ в составе матрицы и обработка биокомпозита гидрофобизатором Rucostar DDD способствует снижению гидрофильности. Выяснено, что состав полимерной матрицы существенно влияет на кинетику разложения биокомпозитов в почве. Экспериментальные результаты свидетельствуют о возможности использования полимерных матриц различного состава для получения армированных биокомпозитов с достаточно широким диапазоном свойств и регулируемой способностью к биоразложению. 